\title{
Radiolarians and terranes: Mesozoic geology of Japan
}

\begin{abstract}
Nobody can understand the geology of Japan without the knowledge of radiolarian biostratigraphy and the concept of terranes. In the past decade, considerable research has been carried out on radiolarian fossils, particularly those in the basement rocks of Paleozoic and Mesozoic ages. The results indicate that Jurassic formations are widespread and that they constitute an accretionary complex. After establishing a new series of radiolarian fossil zones, we have reexamined the stratigraphy of the basement rocks and have recognized many tectonostratigraphic terranes in the Japanese Islands. Discussion on the tectonic history of the Mesozoic terranes is extended to that of eastern Asia in relation to accretion and dispersion processes.
\end{abstract}

\section{Introduction}

The Paleozoic to Mesozoic group of rocks underlies a major part of the Japanese Islands, and it has been investigated stratigraphically since the 19th century, chiefly on the basis of fusulinaceans and macrofossils. In contrast to this school of biostratigraphy, studies of radjolarians (rads), particularly using the scanning electron microscope, were undertaken in the 1970 s and became widely popular thereafter. In fact, of more than 400 papers published on rads in Japan since 1926, more than 80 percent appeared in the 1980s. These papers, written mainly by enthusiastic young geologists, have offered startling new evidence for the geologic age of the "Paleozoic" group. The most noticeable papers present the findings of Jurassic rads from "Paleozoic" provinces, and it has been demonstrated that the "Paleozoic" group actually forms a Mesozoic mélange complex.

It used to be believed that paleogeographic reconstruction could be made by collecting paleoenvironmental data and by compiling them according to their ages and similarities. However, the newly obtained age data have revealed that adjoining geologic units bounded by a significant discontinuity have different geologic histories. The terrane concept has been accepted, and the term is used now especially by the geologists who have been working in the "Paleozoic" provinces.

Thus, the geology of the Japanese Islands prior to the opening of the Sea of Japan is discussed here in terms of collage tectonics on the eastern continental margin of Asia in Mesozoic time.

\section{Radiolarian biostratigraphy of the Paleozoic to Mesozoic group}

$\mathbf{R}_{\text {adiolarian biostratigraphic research and age assignment by mean }}$ of rads were not done successfully until the 1970s. Our knowledge of rads has improved greatly, however, in the past decade, which is shown by several leading papers such as those written by Nakasek: and Nishimura (1979) on Late Triassic rads. Yao and others (1980) on Middle Triassic to Middle Jurassic rads, Mizutani and other (1981) on Middle to Late Jurassic rads, and Ishiga and Imoto (1980, on Permian rads.

Mesozoic radiolarian assemblage zones were set up first by $\mathrm{Ya}$ : and others (1980) in chert-clastic sequences that were assigned to the Middle Triassic to Middle Jurassic on the basis of conodonts and stratigraphic relationships. Subsequently. many assemblage zone: have been proposed, though locally, that range in age from Permian to Cretaceous. Integrating these data with their own observations Matsuoka and Yao (1986) established the Jurassic rad zones as defined by biohorizons. At present, the rad zones in Japanese late Carboniferous to Jurassic time are compiled as shown in figure 1. Ot these zones, the Jurassic ones are correlated broadly with the rad zones of the Atlantic Ocean, Mediterranean Tethys, and North Amer ican regions (Yao, 1990). According to the latest report of the Ocean Drilling Program (ODP), the rad zones of late Middle Jurassic to, earliest Cretaceous time in the central western Pacific Ocean floor correspond well to those of the Japanese Islands.

Systematic investigations of "Paleozoic" stratigraphy and the age assignments based on our rad scale indicate that chert or siliceous shale in the "Paleozoic" group commonly contains rads of Permian. Triassic, or Jurassic ages. The occurrences of these rads suggest that the group is a mélange complex that is composed principally of a Carboniferous to Permian greenstone and limestone (seamount) fa cies; a Carboniferous to Permian shale and chert (pelagic) facies; and a Triassic bedded chert, Jurassic chert and siliceous shale (sometimes, carrying manganese carbonate nodules), and Jurassic clastic facies in which granite-bearing conglomerate is intercalated sporadically.

\section{Mesozoic terranes of the Japanese Islands}

We have reviewed and reexamined all the classic data in order to present the whole tectonic history of the Japanese Islands, where we have recognized many disparate terranes as shown in figure 2 . They are metamorphic terranes (Hida, "Sangun," Sanbagawa, and Abukuma), Paleozoic terranes composed mainly of Paleozoic folded formations (Akiyoshi and South Kitakami), an early Mesozoic terrane (Maizuru), mélange and disrupted terranes (Mino, Chichibu. and North Kitakami), a much younger terrane of an accretionary complex (Shimanto), and the Cenozoic terrane of Izu. Our discussions extend to intraterrane features and to interterrane relationships 


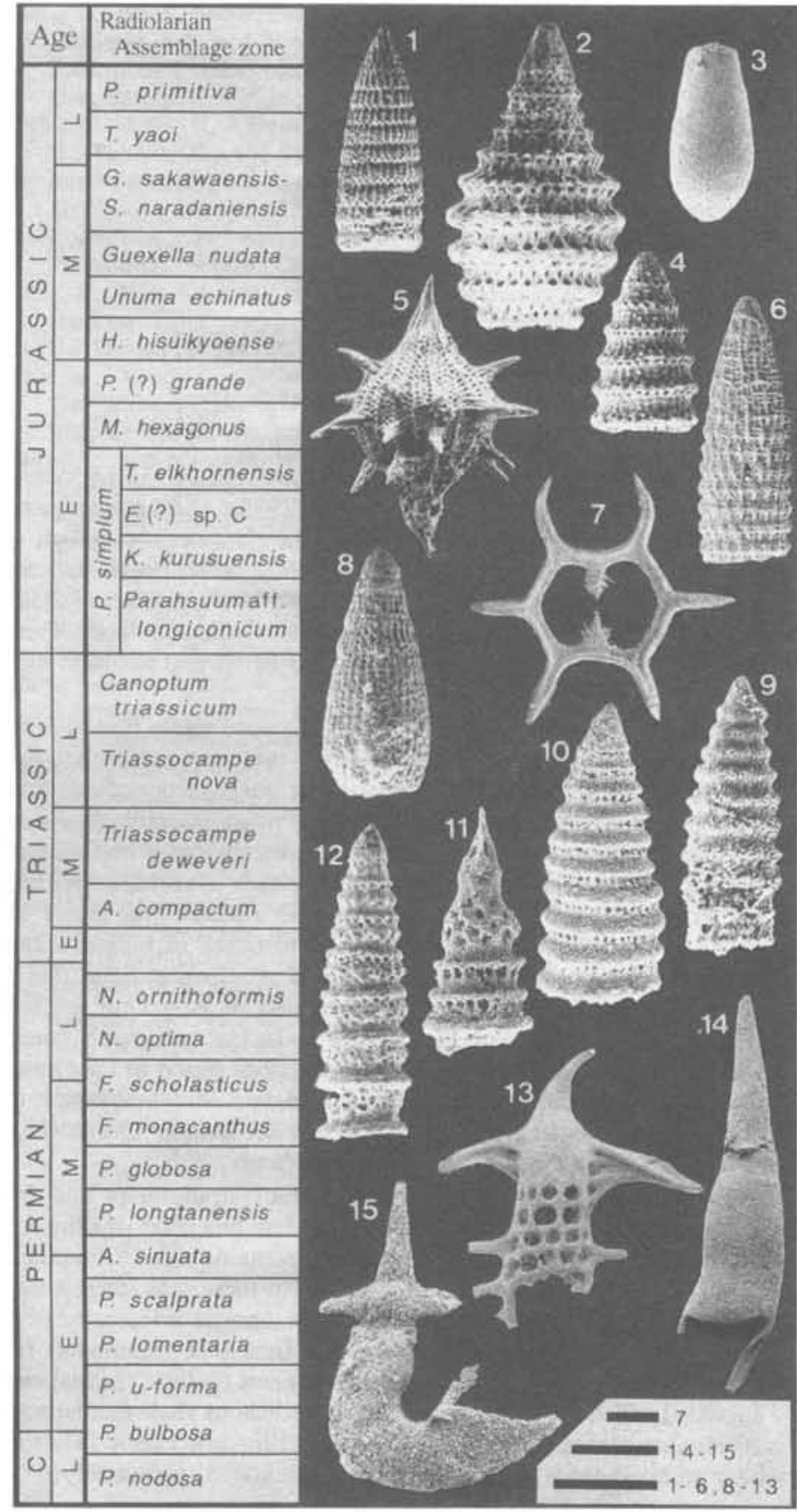

The Hida terrane, for example, consists of a granitic, polymetamorphosed basement complex ranging in age presumably from the Precambrian to the Triassic, and it is overlain unconformably by a Jurassic to Cretaceous clastic sequence. It is juxtaposed with the Mino terrane of a mélange complex, which is composed of a Jurassic radiolarite, a Triassic bedded chert, and a Permian greenstonelimestone mass that is associated with coeval shale and chert, all enclosed in Jurassic to Lower Cretaceous clastic deposits. These two terranes, the Hida and Mino, were stitched together by Upper Cretaceous to lower Paleogene rhyolite effusive rocks. Between the Hida and Mino terranes, a suture zone exists as a narrow tectonic belt, in which irregular blocks of varying sizes (serpentinite, greenschist, and blueschist associated with metamorphosed ophiolitic rocks, middle to upper Paleozoic limestone, clastic rocks, and volcanic rocks) are
Figure 1.-Late Carboniferous to Jurassic radiolarian fossils and their assemblage zones in the Japanese Islands. (I) Pseudodictyomitra primitiva Matsuoka and Yao. (2) Parvicingula mashitaensis Mizutani. (3) Gongylothorax sakawaensis Matsuoka. (4) Dictyomitrella(?) kamoensis Mizutani and Kido. (5) Unuma echinatus Ichikawa and Yao. (6) Hsuum hisuikyoense Isozaki and Matsuda. (7) Mesosaturnalis hexogonus (Yao). (8) Parashuum simplum Yao. (9) Canoptum triassicum Yao. (10) Triassocampe nova Yao. (11) Yeharaia elegans $\mathrm{Na}$ kaseko and Nishimura. (12) Triassocampe deweveri Nakaseko and Nishimura. (13) Neoalbaillella ornithoformis Takemura and Nakaseko. (14) Follicucullus scholasticus Ormiston and Babcock. (15) Pseudoalbaillella u-forma Holdsworth and Jones. Scale bar equals $0.1 \mathrm{~mm}$. Abbreviations: $C$, Carboniferous; E, Early; M, Middle; L, Late. In Jurassic and Triassic ages: T. yaoi, Tricolocapsa yaoi; S. naradaniensis, Stichocapsa naradaniensis; P.(?) grande, Parahsuum(?) grande; T. elkhornensis, Trillus elkhornensis; E., Eucyrtidiellum; K, Katroma; A. compactum, Archaeospongoprunum compactum. In Permian and Carboniferous ages: N., Neoalbaillella; F., Follicucullus; P., Pseudoalbaillella; A., Albaillella.

sliced and interleaved together. Some of the fragmentary units in this suture zone can be correlated with those of the Akiyoshi and "Sangun" terranes.

The Akiyoshi terrane is composed principally of Carboniferous to Permian limestone and underlying greenstone plus Permian chert and shale; all of these are deformed severely and are overlain unconformably by slightly deformed, Triassic, coal-bearing formations. The Paleozoic group in the Akiyoshi terrane represents an older accretionary complex that was related to the collision and disruption of ancient seamounts, which were associated with the surrounding pelagic chert and shale during latest Permian time. The Akiyoshi terrane itself has undergone no intense metamorphism, whereas the "Sangun" and Sanbagawa terranes are metamorphic terranes that are composed commonly of metamorphic rocks of greenschist to blueschist facies. Isotopic ages of the "Sangun" metamorphic rocks reveal that three metamorphic events are detectable or that the terrane may well be composed of three subterranes; the metamorphic events are supposed to be of Carboniferous to Permian, Triassic, and (or) Jurassic ages. On the other hand, the isotopic ages of the metamorphic rocks of the Sanbagawa terrane range from 128 to $50 \mathrm{Ma}$ and cluster in the interval from 110 to $60 \mathrm{Ma}$.

The Chichibu terrane is another mélange and disrupted terrane that extends much of the length of the Japanese Islands on the Pacific side. It is sometimes divided into two subterranes, North Chichibu and South Chichibu, between which the Kurosegawa terrane is sliced in a fragmentary fashion (these subterranes and the Kurosegawa terrane are so small in size that they are not shown in fig. 2).

As has been pointed out by Saito and Hashimoto (1982), the South Kitakami terrane is an exotic allochthonous mass. It consists of a successive sequence, though bounded by numerous unconformities, that is composed of Silurian shallow-sea carbonate, Devonian acidic volcanic rocks, Carboniferous shallow-sea carbonate (interrupted by late Carboniferous folding), Permian shallow-sea carbonate overlain by coarse clastic deposits, and Mesozoic clastic deposits of a shelf facies. All these formations are similar to those of the Kurosegawa terrane.

The North Kitakami terrane, chiefly a Jurassic mélange complex, has many traits in common with the Mino terrane or with the Chichibu terrane of southwestern Japan. The North Kitakami terrane is bounded on the south by a narrow suture zone, where an ophiolitic complex is found to occur together with sheared slivers derived from the North Kitakami and the South Kitakami terranes. The Abukuma 


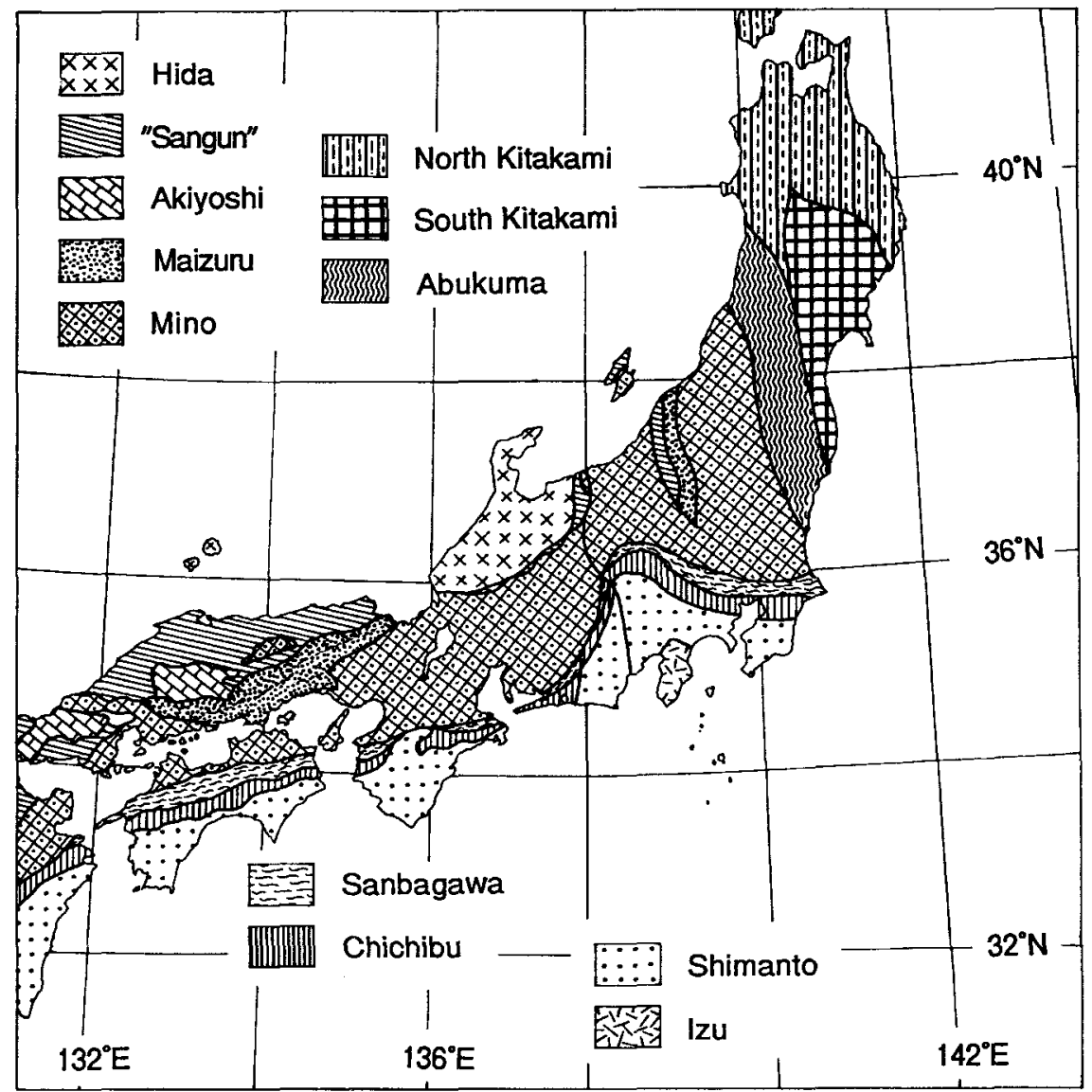

Figure 2.-Major terranes of the Japanese Islands (modified and redrawn on the basis of the terrane map of Ichikawa, 1990). terrane to the south and southwest of the North and South Kitakami terranes is composed of metamorphic rocks that probably were derived from a Jurassic sedimentary complex.

\section{Mesozoic tectonic history of the eastern continental margin of Asia}

Along this trend of biostratigraphic studies in Japan, a reconnaissance survey has been carried out on the Asian continent as well. The Nadanhada area, located in the northeastern part of China, is one such example where the geology was reexamined by using rads and terrane analysis (Kojima, 1989). This work has disclosed that the Nadanhada terrane is identical to the Mino terrane in all aspects. The comparative studies indicate that the Nadanhada and Mino terranes once formed a single large terrane prior to the opening of the Sea of Japan. By referring to the terrane map of China, we conclude that the eastern margin of Asia formed a collage zone of terranes in Jurassic to Cretaceous time.

In order to discuss the process by which these terranes were accreted, dispersed, and positioned finally at their current locations, the following two paleomagnetic investigations are worthy of note. Shibuya and Sasajima (1986) determined, after making a thorough examination of the folded Triassic bedded chert of the Mino terrane, that the rock was magnetized originally in the equatorial region. $\mathrm{Z}$. Zheng (written communication, 1991) reported that the Upper Jurassic and Lower Cretaceous siltstones and shales in the Nadanhada Range have paleomagnetic inclinations corresponding to a paleolati- tude of approximately $33^{\circ} \mathrm{N}$. In addition, the presence of lutecite in a Permian limestone block that is embedded within the Jurassic mélange complex of the Mino terrane suggests that the block probably was derived from the current southern China region, because no lutecite has been reported elsewhere so far, except in a platform region of southern China (Hattori, 1989).

Terrane accretions are inferred to have occurred in the southeastern peripheral zone of Asia after the formation of a collage of Triassic age in the main part of eastern Asia (fig. 3). Permian seamounts and Triassic bedded chert formations, both coming from the equatorial region, assembled together with the pelitic sediments of Jurassic age, and all were enclosed within the coarse clastic sediments derived from an older continental region. It is highly probable that the ophiolites in the suture zones between major terranes of the Japanese Islands represent an ancient oceanic crust that existed at the time of accretion. All terranes of Jurassic to Cretaceous age in the collage zone were transpressed, dispersed, and displaced along the margin up to northeastern China and the Sikhote-Alin region of the USSR, so the prevailing movement had to be of a sinistral sense. Most of the terranes were sliced and fragmented during this period, and strike-slip movements took place in a continental region and within the collage zones. Metamorphism was closely related to this tectonic history, as the accretion in Late Jurassic to Early Cretaceous time and the transpression in the ensuing time are, above all, responsible for the formation of the metamorphic terranes.

After extensive acidic magmatism of Late Cretaceous to early Tertiary time in the continental margin, rifting occurred within the collage zone. This is represented by Neogene andesitic volcanogenic 


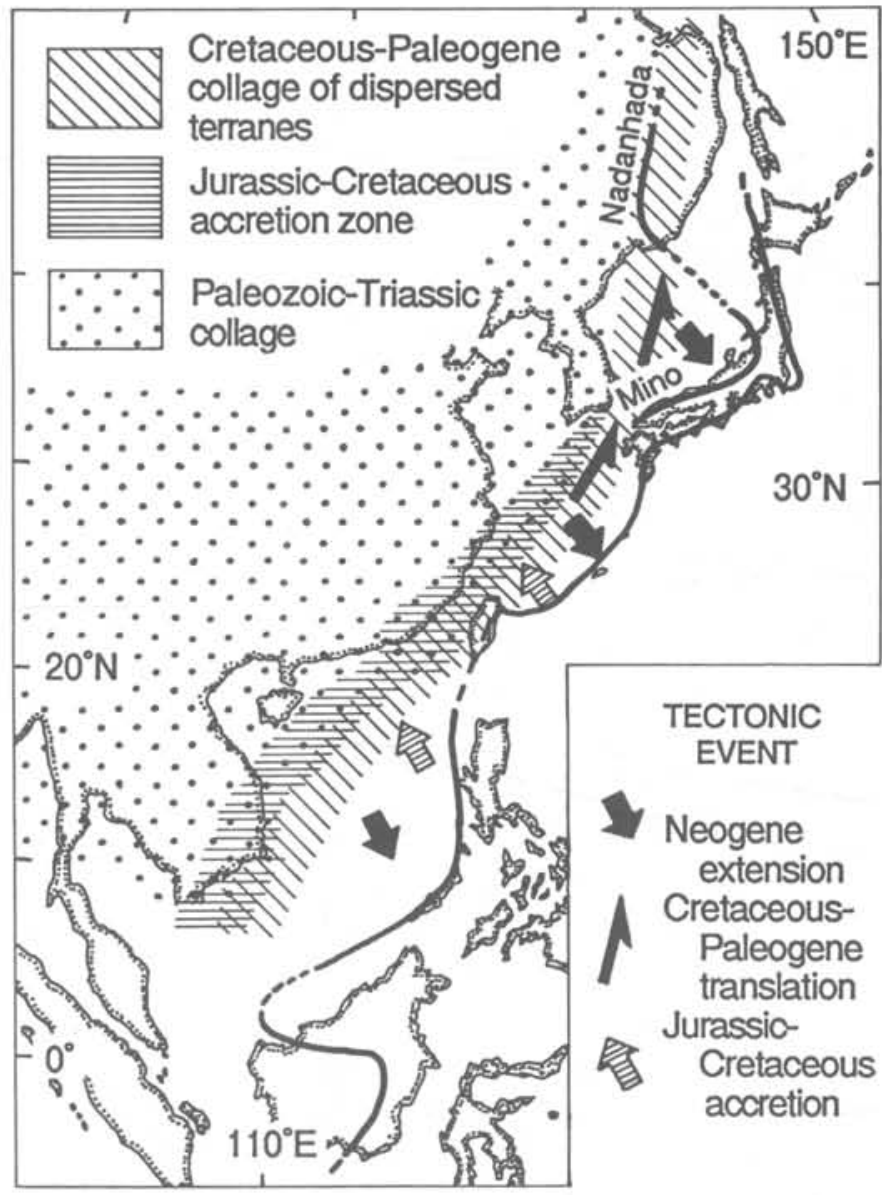

Figure 3.-Brief summary of the tectonic history of the Mesozoic terranes of the Japanese Islands (modified and redrawn on the basis of the map by Mizutani and others, 1990). Solid heavy line shows the structural trend of the Jurassic accretionary complexes (Mino and Nadanhada terranes on the Sea of Japan side and Chichibu and North Kitakami terranes and their southern equivalent on the Pacific Ocean side). Dashed heavy line shows a connection of corresponding terminations of the trend that was displaced exclusively by Cenozoic movement.

rocks, generally called Green Tuff, that commonly are found in the Sea of Japan side of the Japanese Islands. This event stands for an incipient stage of extension in the island-arc formation and was followed by the opening of the Sea of Japan.

\section{References}

Hattori, I., 1989, Length-slow chalcedony in sedimentary rocks of the Mesozoic allochthonous terrane in central Japan and its use for tectonic synthesis, in Hein, J.R., and Obradovic, J., eds., Siliceous deposits of the Tethys and Pacific regions: New York, Springer-Verlag. p. 201-215.

Ichikawa, K., 1990, Pre-Cretaceous terranes of Japan, in Ichikawa, K., Mizutani, S., Hara, I., Hada, S., and Yao, A., eds., Pre-Cretaceous terranes of Japan: Osaka, Japan, Osaka City University, Publication of International Geological Correlation Programme Project 224, p. $1-12$.

Ishiga, H., and Imoto, N., 1980, Some Permian radiolarians in the Tamba District, Southwest Japan: Earth Science (Chikyu Kagaku), v. 34, p. 333-345.

Kojima S., 1989, Mesozoic terrane accretion in Northeast China, SikhoteAlin and Japan regions: Palaeogeography, Palaeoclimatology, Palaeoecology, v. 69 , p. 213-232.

Matsuoka, A., and Yao, A., 1986, A newly proposed radiolarian zonation for the Jurassic of Japan: Marine Micropaleontology, v. 11, p. $91-106$.

Mizutani, S., Hattori, I., Adachi, M., Wakita, K., Okamura, Y., Kido, S., Kawaguchi, I., and Kojima, S., 1981, Jurassic formations in the Mino area, central Japan: Proceedings of the Japan Academy, v. 57, series B, p. 194-199.

Mizutani, S., Shao, J., and Zhang, Q.L., 1990, The Nadanhada terrane in relation to Mesozoic tectonics on continental margins of East Asia: Acta Geologica Sinica, v. 3, p. 15-29.

Nakaseko, K., and Nishimura, A., 1979, Upper Triassic Radiolaria from Southwest Japan: Osaka, Japan, Science Report of College of General Education, Osaka University, v. 28, p. 61-109.

Saito, Y., and Hashimoto, M., 1982, South Kitakami region: An allochthonous terrane in Japan: Journal of Geophysical Research, v. 87, p. 3691-3696.

Shibuya, H., and Sasajima, S., 1986, Paleomagnetism of red cherts: A case study in the Inuyama area, central Japan: Journal of Geophysical Research, v. 91, p. 14105-14116.

Yao, A., 1990, Triassic and Jurassic radiolarians, in Ichikawa, K., Mizutani, S., Hara, I., Hada, S., and Yao, A., eds., Pre-Cretaceous terranes of Japan: Osaka, Japan, Osaka City University, Publication of International Geological Correlation Programme Project 224, p. $329-345$.

Yao, A., Matsuda, T., and Isozaki, Y., 1980, Triassic and Jurassic radiolarians from the Inuyama area, central Japan: Journal of Geosciences, Osaka City University, v. 23, p. 135-154.

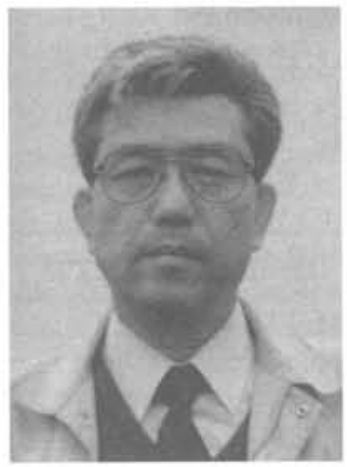

Dr. Shinjiro Mizutani, born in 1932, is Professor of Geology at the Department of Earth Sciences, Nagoya University, Nagoya 464-01, Japan. His research activities concern the geology of Paleozoic and Mesozoic groups and the petrology of sedimentary rocks such as chert and graywacke. In the past decade, he has been involved in research projects on radiolarian biostratigraphy, terrane analysis, and Mesozoic tectonic history of eastern Asia.

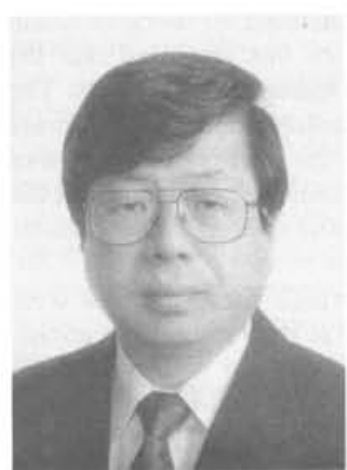

Dr. Akira Yao was appointed to the Department of Geosciences, Osaka City University, Japan, in 1973. He obtained his doctorate from the same university in 1983 by doing radiolarian biostratigraphic work on the Mesozoic sedimentary complex of southwestern Japan. Recently, he has devoted himself to the paleontological study of Paleozoic and Mesozoic radiolarians and to geohistorical research on the eastern continental margin of Asia. 